\title{
The Preferred Learning Modes of Online Graduate Students ${ }^{1}$
}

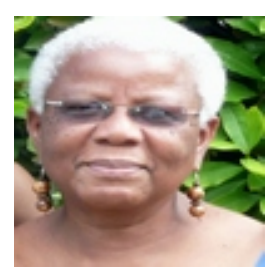

Olabisi Kuboni

University of the West Indies Open Campus, Trinidad and Tobago

\section{Abstract}

This paper reports on a research project aimed at identifying the preferred approaches to learning of mature students in an online graduate programme. Interest in this issue was generated by the positions taken by certain theorists who argue for less focus on interaction and collaboration as the basis for learning in the online environment. They contend that the learner as an individual should be acknowledged. A questionnaire, operationalizing four learning modes, was used to solicit responses from graduate students. The modes were independent learning, instrumental learning, interactive learning, and collaborative learning. Factor analysis confirmed the four as student preferred learning modes. In addition it allowed for the emergence of specific attributes of each. While instrumental learning emerged as a strong factor, the most dominant construct emerging was a dimension of collaborative learning. It is envisaged that the findings of the study can inform the design of online teaching-learning strategies for this category of students.

Keywords: Independent learning; instrumental learning; interactive learning; collaborative learning; mature graduate students; online learning

${ }^{1}$ An earlier version of this paper was presented at the AACE 2011 World Conference on e-Learning. 


\section{Introduction}

Perspectives on online education over the last several decades have focussed more on learning as an activity that entails interaction and collaboration (Henri, 1992; Haughey \&Anderson,1998; Hendricks, 2012) than as an individual activity. Notwithstanding this consensus, there are those who hold reservations about this perspective. For example, Annand (2007) contends that requiring students to engage in social interaction conflicts with learner autonomy, given the capacity for self-pacing that the new digitized media allows students of the post-industrial era (p.1). Asunka (2008), based on his study of online learning in a higher education institution of sub-Saharan Africa, contends that less emphasis should be placed on online discussions and group activities and more on those activities that require individual responses to assignments and exercises (p. 12). Dixon, Dixon, and Siragusa (2007) offer a similar perspective. Drawing on the findings of their study among adult learners, they conclude,

... the majority of students preferred to work alone and felt that they possessed learning styles that did not necessarily lend themselves to collaboration. They appeared to want to take greater responsibility for their learning as adults and this did not include working with peers. (p. 213)

The University of the West Indies Open Campus (UWIOC) began its online offering of postgraduate programmes in January 2010, drawing its intake primarily from the populations of the 15 English-speaking countries supporting the University. Notwithstanding the apparent tension between the perspectives cited above, the teaching-learning space for these programmes is designed to support interaction and collaboration in the learning process as well as to build the capacity of individual students to function as independent learners. The thinking informing this approach to the design is that ability to engage in shared learning and being able to take responsibility for one's own learning should be viewed as complementary rather than mutually exclusive.

Prior to the start of their programme, students are required to participate in a threeweek non-credit orientation course that is designed to support newly admitted students to

- monitor and evaluate their learning;

- produce academic writing that meets accepted standards for work done at the postgraduate level;

- source, evaluate, and use information to meet the requirements of a given task, assignment, or research undertaking;

- interact with other learners in a manner that facilitates shared learning. 
The formal credit programmes, like the orientation course, are conducted in a webbased learning management system and are built around the following core features:

- fully developed self-study materials with accompanying resources and builtin activities for self-assessment,

- links to other sites to facilitate student-initiated searches,

- required interaction throughout the study period among the learners and between learners and group facilitators,

- learner participation in specially-designed collaborative activities,

- continuous assessment with informational feedback.

The programmes are delivered over three 13-week trimesters in a calendar year.

This study was undertaken to determine whether the preferred learning modes of graduate students of the UWI Open Campus are consistent with those that underpin the design of the online learning environment.

\section{Significance of the Study}

While the academic and research literature provides important perspectives to guide practice, this researcher holds the view that practice must also be informed by data emerging from the context in which it is taking place. This study is intended to yield findings that provide greater insight into the learning preferences of mature graduate students of the English-speaking Caribbean. It is also envisaged that it will contribute to the body of principles applicable to the design of online teaching and learning systems in socio-cultural contexts similar to the one in which the study is being conducted.

\section{Literature Review}

This study is designed around four principles of learning. As mentioned above, two of them, interactive learning and collaborative learning, are the ones that many analysts and practitioners consider to be most relevant for online learning. The third, independent learning, is included for reasons cited above, even though it is not given as much prominence as the other two in the literature. Instrumental learning is being added. As will be discussed later, an outlook on learning as being instrumentalist is considered to be embedded in the didactic strategies employed in traditional classroombased instruction. This researcher has previously acknowledged the challenge that online practitioners face in addressing the reliance on top-down approaches that characterise the learning experience of some mature students (Kuboni, 2009).

\section{Instrumental Learning}

Many analysts in the field of adult education hold the view that instrumental learning can undermine efforts to facilitate meaningful learning. Hyland and Merrill (2003), for 
example, are concerned that "imagination and creativity are often stifled in the pursuit of behaviourist learning outcomes or instrumental employability" (p.169). Devos (2002), looking specifically at learning in the workplace, highlights the work of Marsick and Watkins (1990) who, she claims, have contributed to moving the discussion away from "a narrow instrumentalist approach", which she sees as reflecting "the limits of behaviourism".

Rust (2009) takes a more micro perspective. In outlining the tenets that, in his view, should inform assessment practices in the adult education sector, he cautions against instrumentalist approaches and calls for a greater emphasis on "assessment for learning rather than assessment of learning". He explains further,

[T] he balance of current practice has shifted too far towards the summative assessment of students and attempts to measure what they have learnt at given points, linked to the awarding of grades and/ or marks. This arguably leads to instrumentalism by students ...Instrumentalist students are likely to adopt a "tick box" mentality, moving on to the next unit or module without seeing any connection between past and future learning. (p. 124)

\section{Instrumental and/or instrumentalist learning: An explanation.}

Instrumentalist learning derives from a philosophical base, while instrumental learning has its origins in Skinner's theory of behaviourism. Nonetheless, in the context of this study, both are regarded as carrying the same core meaning.

One dictionary definition views instrumentalism as "a pragmatic theory that ideas are instruments that function as guides of action, their validity being determined by the success of the action." 2 When applied to learning what emerges is an understanding of an activity that is basically utilitarian, and intended to ensure the successful completion of a particular task rather than the development of the learner. A similar view can be detected in instrumental learning, which has its origins in Skinner's operant or instrumental conditioning. The core attribute of Skinner's learning theory that resonates within instrumental learning is the attainment of desired outcomes through the use of appropriate conditioning techniques. Operant or instrumental conditioning holds that a behaviour may be elicited and ultimately strengthened if that behaviour is followed by some appropriate reinforcing stimulus (Gray, 1996).

For the purpose of this study, the term being used is instrumental learning.

\footnotetext{
${ }^{2}$ http://www.thefreedictionary.com/instrumentalism
} 


\section{Independent Learning}

As stated earlier, independent learning does not occupy a prominent position in the literature on online learning given the capability of the web-based environment to support social interaction. Some would argue though that one's ability to engage in shared learning with others depends not only on facilitating environmental factors, but more importantly on one's ability to take responsibility for and manage one's own learning. It is in that context that it was considered appropriate to investigate the extent to which this approach to learning was a feature of the learning mode of the participants of this study.

The notion of the independent (or autonomous) learner can be traced to two main contexts. In one instance, it features in the field of adult learning, in particular through the related concepts of lifelong learning and self-directed learning (Candy, 1991; Merriam, Caffarella, \& Baumgartner, 2007). In open and distance learning, it gained prominence as a key attribute for distance learners in the era when distance education was targeting a mass, widely distributed audience through the use of the second generation technologies, which offered limited scope for interactivity (Laurillard, 1993; Postle, 2002). The reality of physical separation, both from the teaching institution and from other learners, necessitated the development of learner qualities that would allow for self-management and the capability to take responsibility for one's learning. The work of two theorists stands out in this regard.

Wedemeyer, who originally conceptualised independent study as applying to both the "internal" and "external' student", ultimately acknowledged its significance in open and distance learning and in that context offers the following explanation:

Independent study consists of various forms of teachinglearning arrangements in which teachers and learners carry out their essential tasks and responsibilities apart from one another, communicating in a variety of ways ... Independent study programs offer learners varying degrees of freedom in the self-determination of goals and activities. (1975, p.11)

Moore's theory of independent learning and teaching is clearly located in the context of what he refers to as "distance teaching". Moore holds that a distinction needs to be made between "two major classes of learning environment", namely "contiguous situations", where teacher and learners are in close physical proximity to one another, and "distant situations" where they are separated and where some other form of communication is required to bridge the gap. Moore asserts that the influence that the distance exerts requires that learners accept a high level of responsibility for their learning and that this is a core characteristic of an autonomous learner (1973, pp. 663664). As noted earlier, while most theorists focus on learning in the online environment as an interactive activity, others contend that the focus should be on individual activity 
(Dixon et al., 2007; Asunka, 2008; Annand, 2007). Indeed Anand goes further and asserts that it is the qualities of independence and autonomy that are to be emphasized. While the advocates of social interaction point to the capability of the interactive technologies of the environment to support learning through interpersonal interaction, Anand draws attention to the digital technologies that, in his view, provide a stronger case for a focus on independent learning. Specifically, he contends that the digitized media make it possible for learners to take over some of the instructor roles and to adopt "new forms of learning through searching, evaluating, managing and retrieving material" (2007, p. 1).

While not minimising the importance of the debate outlined above, it should be noted that other theorists propose an understanding of online learning as a multi-dimensional construct. Hong and J ung (2011), in their three-phased study, identify five clusters of distance (including online) learning competencies, namely study vision, cognitive and meta-cognitive skills, interaction abilities, identity as a learner, and management skills. With regard to the second cluster, they explain that it embodies skills that demonstrate, inter alia, an ability to plan and regulate one's learning, select methods according to one's preferred learning styles and circumstances, and make adjustments in one's studies when failures or shortcomings are apparent (p. 31). All of these attributes can readily be recognised as being consistent with independent learning. The authors apply the label "interaction abilities" to the third cluster. All of the foregoing perspectives on independent learning, whether viewed separately or as part of a set of learning capabilities, have contributed to the approach taken to the design of this study.

\section{Interactive Learning}

The role of interaction in learning at a distance was an area of focus for theorists and practitioners even during the industrialization era (Daniel \& Marquis, 1989; Moore, 1989). However, the introduction of the interactive ICTs has allowed for a greater focus on interpersonal communication (Cookson \& Chang, 1995; Wagner, 1994; Shackleford \& Maxwell, 2012), and more specifically on the role of social interaction in the act of learning (Kaye, 1992; Rovai, 2002). Nichani (2000), in making his case for an online learning community, supports the view advanced by Brown and Duguid (2000) who assert as follows:

Despite the tendency to shut ourselves away and sit in Rodinesque isolation when we have to learn, learning is a remarkably social process. Social groups provide the resources for their members to learn.

Using the term collaborative learning in a manner synonymous with the phrase interactive learning in this paper, Hendricks (2012) provides various interpretations to explain the nature of learning that takes place in a social context. Taking as his starting point, the constructivist view, which holds that knowledge is built socially through inquiry and reflection, he describes collaborative learning as follows: 
[It] allows for student interaction with more capable peers and less capable peers in order to master critical concepts or skills using language as a necessary tool to negotiate and renegotiate meaning/ knowledge. (p. 41)

In a similar vein, Ryle and Cumming (2007) draw attention to the role that social interaction, dialogue, and reflection play in the creation of new knowledge and deep learning.

Many theorists use the context of the community, and more specifically the learning community, to present their perspective on interactive learning. Yang, Yeh, and Wong (2010), for example, posit,

In a community, meaningful learning is achieved by interaction, and people share individual resources, elicit challenging questions and provide constructive feedback so as to enhance personal intellectual growth. (p. 288)

While, as was mentioned earlier, the introduction of the interactive technologies would have influenced the emergence of this enhanced focus on learning through interaction, one cannot overlook the simultaneous thinking at the psychological/philosophical level that was not necessarily tied to the advances in technology but which also influenced the growing interest in the social dimension of learning. The theorists who were spearheading this outlook in the latter part of the twentieth century were doing so against the backdrop of increasing doubts about the appropriateness of the objectivist, behaviourist view of learning (e.g., J egede, 1991; Duffy \&J onassen, 1991).

Thus, J onassen, Davidson, Collins, Campbell, and Haag (1995) assert, "Constructivist environments engage learners in knowledge construction through collaborative activities that embed learning in a meaningful context and through reflection on what has been learned through conversation with other learners" (p. 13).

An important point to note about the perspectives advanced by Jonassen et al. is the seamless connection that they make between learning (namely meaning-making) at the level of the individual learner and at the group level. For them meaning-making involves both internal and social negotiation. Thus they explain, "We debate, wrestle, and argue with ourselves over what is correct, and then we negotiate with each other over the correct meaning of ideas and events" (p. 12).

\section{Collaborative Learning}

In much of the literature of open, distance, and online learning, the term collaborative learning often carries the same interpretation as interactive learning (see for example, Hendricks, 2012). While acknowledging that the two are often used interchangeably, the position adopted for this study is that the meaning of collaborative learning can be regarded as extending along a continuum from learning in a social context to 
engagement in some collaborative activity intended to yield a defined outcome. This latter notion of collaborative learning is reflected in the explanations provided by two noted theorists in the field. Kaye (1992), tracing the origin of the term collaborate back to its Latin root co-labore, meaning to work together, views collaborative learning as any learning that takes place as a result of people working together (p. 2). Harasim, Hiltz, Teles, and Turoff (1995) state, "Collaborative learning refers to any activity in which two or more people work together to create meaning, explore a topic or improve skills" ( $\mathrm{p}$. 30).

For Haythornthwaite (2006), it is working towards a common goal. She elaborates as follows:

Collaboration ... models the way work unfolds outside classrooms. It can emulate and train for future workplace practices, including learning how to share ideas, voice opinions, work on a team, and manage projects. It gives individuals experience in project and group management. Moreover, during their collaboration, students are also doing the important work of learning how to do all this online and gaining skills in online communication and group management. (p. 10)

Also to be noted is the work of J ahng (2012) whose focus is the way problem-solving activities are handled in small groups. She contends that collaboration in a problem solving activity demands complex learning skills for engaging in constructive arguments as well as proposing alternative solutions to reach a consensus for the best solution ( $p$. 2).

The introduction of the social software technologies into the practice of online education has heightened interest in and commitment to the notion of collaborative learning. Citing Allen (2004), Anderson (2008) notes their heightened capacity to support human interaction, decision-making, planning, and other higher level activities. Against that background, he asserts, "Social software provides scaffolding that allows individuals or groups to share, extract, and organize new knowledge and build social relationships" (p. 173).

Also acknowledging these capabilities are den Exeter, Rowe, Boyd, and Lloyd (2012) who cite several earlier works that draw attention to the potential of wikis, blogs, podcasts, and other social software for supporting social interaction and collaborative learning (p. 217).

It is these perspectives on learning that informed the design of this study. 


\section{Research Questions}

In light of the foregoing, this study was based on the following research questions:

- What are the preferred learning modes of UWI Open Campus graduate students?

- Are students' preferred learning modes consistent with those that inform the design of the online teaching space?

\section{Methodology}

\section{Research Design}

The study was based on an online survey conducted among the 2011 and 2012 cohorts of graduate students of the University of the West Indies Open Campus, with a questionnaire being used as the instrument for data collection.

\section{Questionnaire Design}

The questionnaire was built around the four modes of learning described earlier. A first version was developed and informally tested with 21 students of the 2010 cohort. In this initial instrument, the four learning modes discussed above were reduced to three with instrumental learning and independent learning being combined and their representative items developed to reflect a continuum from one to the other. The combined construct was given the name individualistic learning. Based on the responses as well as feedback from peers, this decision was reversed, since it was felt that by merging two, one ran the risk of contaminating the original constructs. By keeping them separate, one could ensure a higher probability that all four would be operationalized in a manner that reflected as close as possible their respective conceptual understandings as advanced in the literature.

The questionnaire was based on a four-point rating scale, ranging from strongly agree to strongly disagree. A four-point rather than a five-point scale was used to minimise the possibility of respondents tending towards the neutral middle option and thus not committing themselves to a clear position. At the same time, recognising that some respondents may feel that their specific position was not considered, an open-ended question was included that allowed respondents the opportunity to give expression to any partial and/or intermediary views they may have that could not be picked up in the scale provided. 
Following are select items from each of the four categories.

Independent learning

- You like flexible course materials that allow you to add your own content.

- You are capable of assessing your own work.

Instrumental learning

- You think that all work should be graded.

- You want the facilitator to respond to your queries as soon as possible after they have been posted.

Interactive learning

- Bouncing ideas off your fellow students helps you to clarify your own thoughts.

- You are comfortable raising counter arguments in a discussion.

Collaborative learning

- You are open to adjusting your input into the overall group activity in order to improve the final outcome.

- You like working with team members to solve problems that come up while doing a project.

In total, 37 closed items were developed in the four categories. Items related to each learning mode were kept together and the categories were presented in the order given above. The questionnaire began with three demographic items, and ended with two open-ended questions, one of which was described above. The second asked respondents to add any other comments they wished to make.

\section{Sampling}

Purposive sampling was employed. Since the first cohort of students was used to test the preliminary draft, all students of the second and third cohorts, totalling 189 students, were targeted for administering the revised version. The two cohorts were considered to be sharing the same basic characteristics, even though, at the time of the survey, each had been in the programme for different periods of time. They were deemed equal since all came from the same broad population. In addition, both cohorts had participated in the three-week orientation course described earlier. 


\section{Data Collection Procedures}

The questionnaire was administered separately to each of the two cohorts during the period May to J une 2012, using the web-based tool Survey Monkey. The link was distributed by blind copy email to ensure that each individual student received it anonymously. Two reminders were sent to each group. Students were advised that the exercise was completely confidential.

\section{Data Analysis Method}

Factor analysis, based on the principal components method of extraction, was used to identify the underlying factors within the main questionnaire items. An independent samples t-test was used on the same data to determine whether there was any significant difference between the two groups in the study.

\section{Findings and Discussion}

Of the 189 students to whom the questionnaire was distributed, 86 or $45 \%$ responded. The majority were in the combined age group 31 - 50, with almost equal numbers in each of the sub-groups. Approximately $75 \%$ described themselves as professionals (Table 1).

Table 1

Demographics of Respondents

\begin{tabular}{|c|c|c|c|c|c|c|c|c|c|c|c|c|c|}
\hline \multicolumn{3}{|c|}{ Gender } & \multicolumn{5}{|c|}{ Age } & \multicolumn{6}{|c|}{ Occupation } \\
\hline Male & Female & $\begin{array}{l}\mathrm{N} \\
\mathrm{R}\end{array}$ & $\begin{array}{l}20 \\
- \\
30\end{array}$ & $\begin{array}{l}31- \\
40\end{array}$ & $\begin{array}{l}41- \\
50\end{array}$ & $\begin{array}{l}\text { Over } \\
50\end{array}$ & $\begin{array}{l}\mathrm{N} \\
\mathrm{R}\end{array}$ & Prof & Admin & Tech & Cler & Other & $\begin{array}{l}\mathrm{N} \\
\mathrm{R}\end{array}$ \\
\hline $\begin{array}{l}6 \\
(7 \%)\end{array}$ & $\begin{array}{l}79 \\
(92 \%)\end{array}$ & 1 & $\begin{array}{l}10 \\
(11 \\
\%)\end{array}$ & $\begin{array}{l}34 \\
(39 \\
\%)\end{array}$ & $\begin{array}{l}32 \\
(37 \\
\%)\end{array}$ & $\begin{array}{l}9 \\
(10 \%)\end{array}$ & 1 & $\begin{array}{l}65 \\
(75 \%)\end{array}$ & $9(10 \%)$ & $\begin{array}{l}3 \\
(3 \%)\end{array}$ & - & $7(8 \%)$ & 2 \\
\hline
\end{tabular}

As noted earlier, the sample comprised two subsets of respondents representing the two cohorts of students. The results of the independent samples t-test showed that there was no significant difference between the two cohorts on seven of the eight factors yielded by the analysis. 
Factor analysis conducted on the responses yielded 11 factors, of which Factors 1 - 8 were retained and the other three discarded (Table 2). A factor was retained if three or more items loaded strongly on it. An item was considered to have loaded strongly if it obtained a factor score of 0.50 or higher.

Using these criteria, nine of the original 37 closed items were discarded. Of these items four each were from the original independent learning and instrumental learning categories, and one from interactive learning. The notion of learning embedded in these items did not appear to be representative of respondents' understandings of their learning preferences. Some of these items loaded weakly on more than one factor. Two examples are, You are capable of assessing your own work, which loaded below 0.50 on two factors, and You work according to a well-organized study plan that you have developed for yourself, which loaded on three factors. The two items that loaded on Factors 9 and 10 respectively were also discarded. Even though both obtained high factor scores, each was the only item associated with that factor.

Table 2

Factor Analysis of Items Loading Above .50

\begin{tabular}{|c|c|c|c|c|c|c|c|c|c|}
\hline \multirow[t]{2}{*}{ Questionnaire item } & \multirow{2}{*}{$\begin{array}{l}\text { Original } \\
\text { construct }\end{array}$} & \multicolumn{8}{|c|}{ Factor loadings } \\
\hline & & 1 & 2 & 3 & 4 & 5 & 6 & 7 & 8 \\
\hline $\begin{array}{l}\text { You are capable of } \\
\text { working with team } \\
\text { members to develop } \\
\text { strategies for carrying } \\
\text { out a project }\end{array}$ & $\begin{array}{l}\text { Collaborative } \\
\text { learning }\end{array}$ & .938 & & & & & & & \\
\hline $\begin{array}{l}\text { You are capable of } \\
\text { working in a team to } \\
\text { create and implement } \\
\text { a project }\end{array}$ & " & .923 & & & & & & & \\
\hline $\begin{array}{l}\text { You like working with } \\
\text { team members to solve } \\
\text { problems that come up } \\
\text { while doing a project }\end{array}$ & " & .899 & & & & & & & \\
\hline $\begin{array}{l}\text { You are comfortable } \\
\text { working in a team to } \\
\text { do an assignment set } \\
\text { by the course } \\
\text { coordinator }\end{array}$ & " & .886 & & & & & & & \\
\hline $\begin{array}{l}\text { You do not feel } \\
\text { insecure when one } \\
\text { member of the team } \\
\text { stands out above }\end{array}$ & “ & .703 & & & & & & & \\
\hline
\end{tabular}




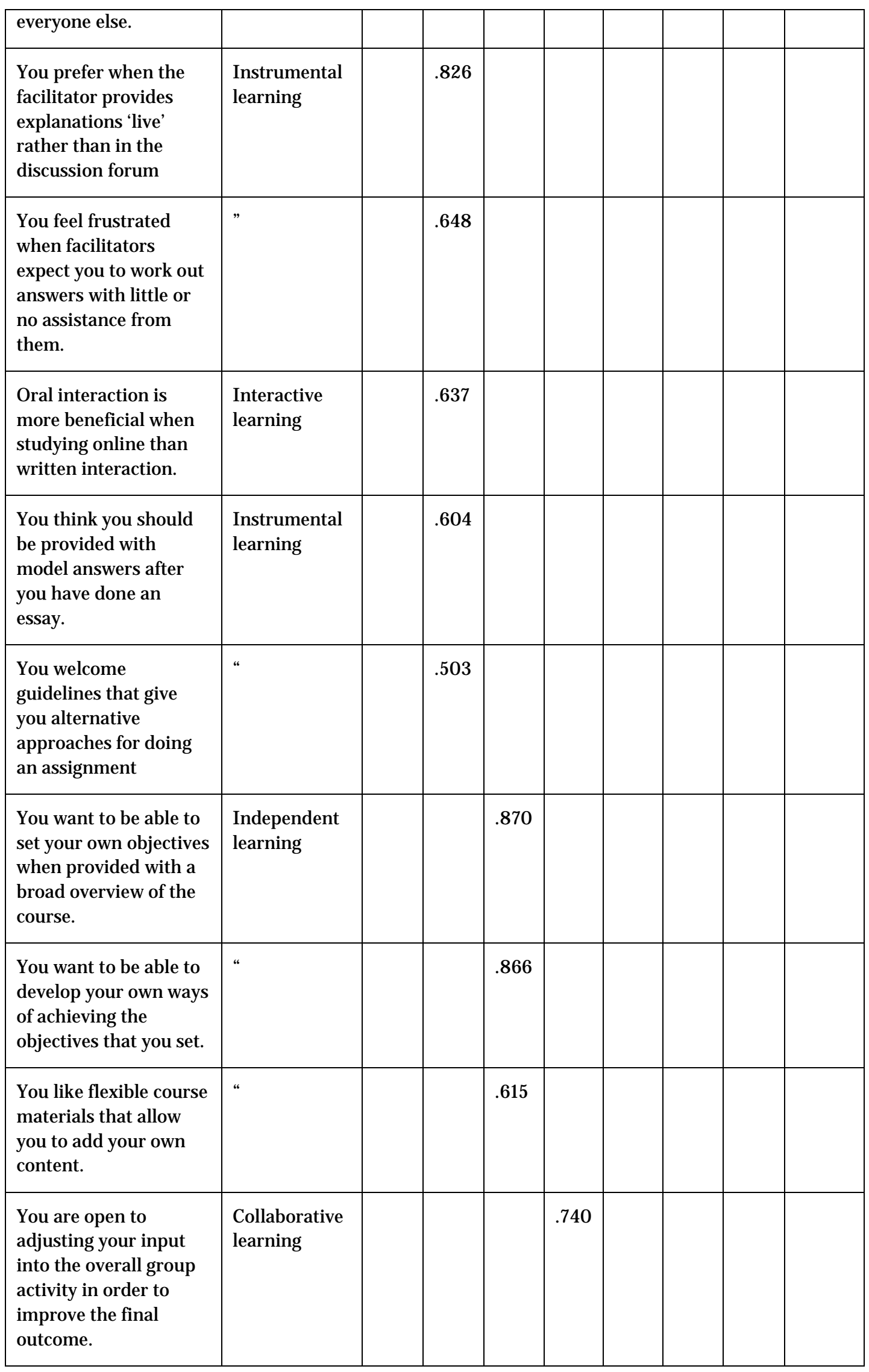




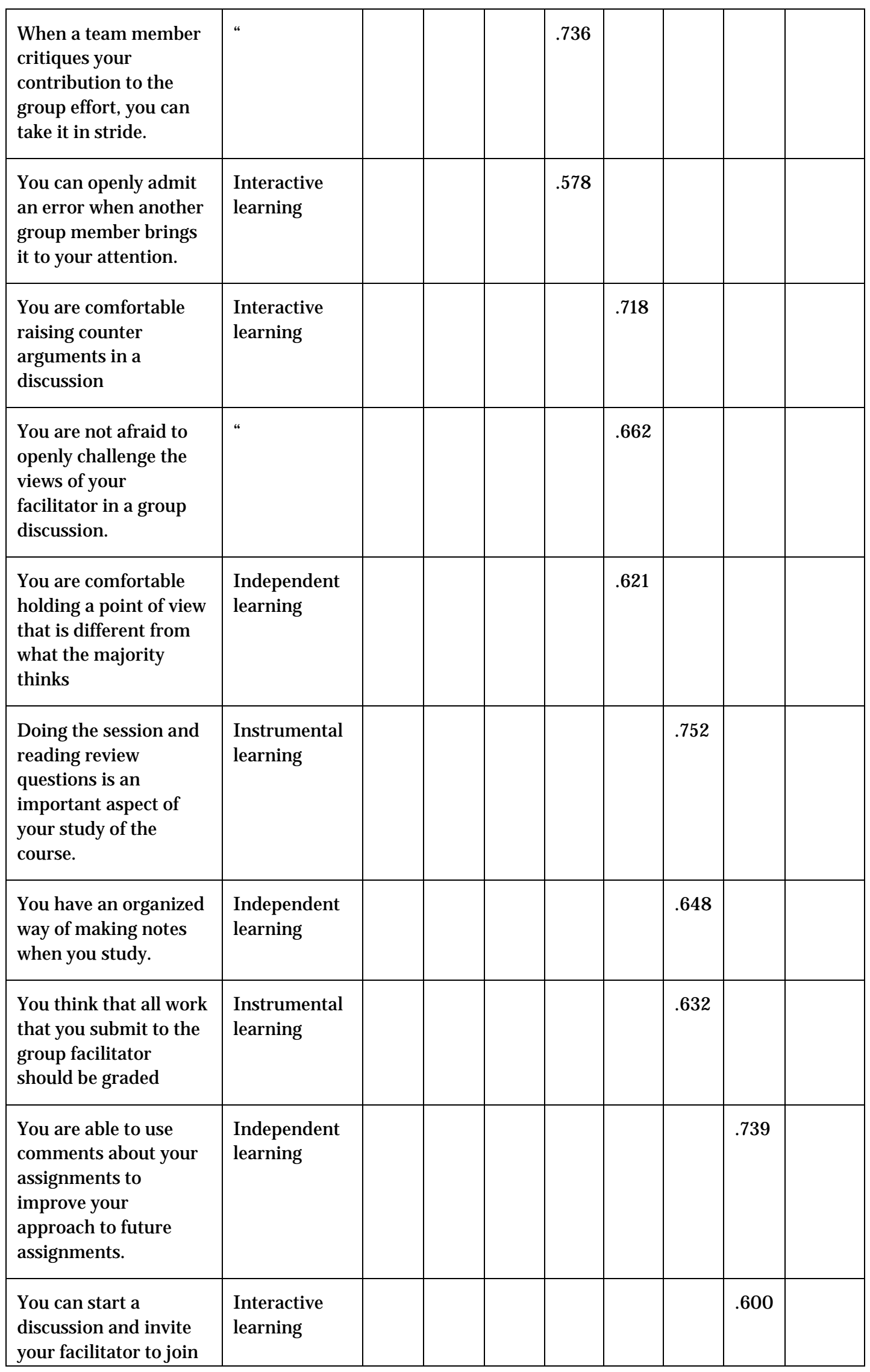




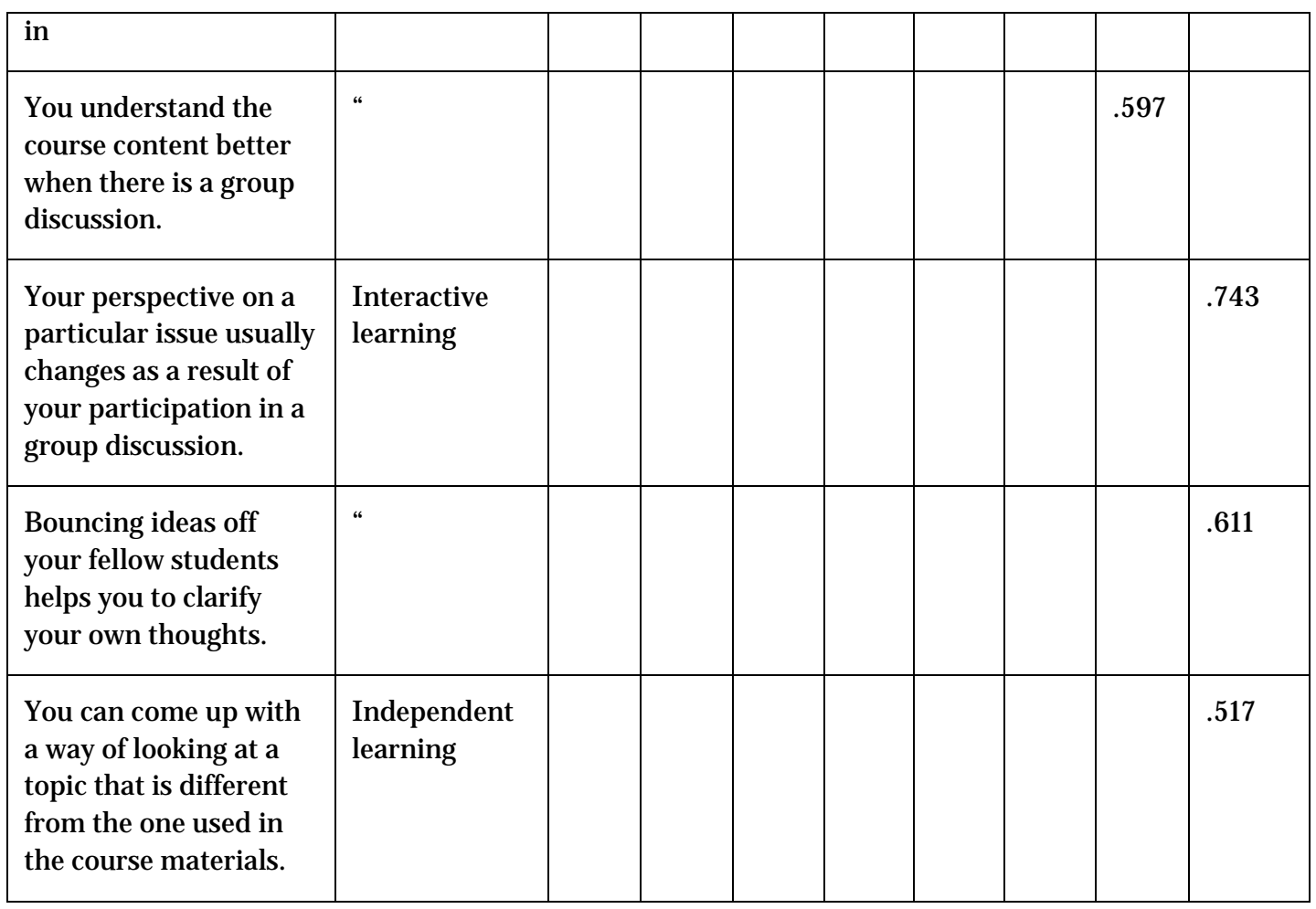

A review of the eight factors retained indicates that generally, notwithstanding some shifts, the factors were associated with items originally developed as variables of the same construct. In addition, that cluster of items could be considered as reflecting one dimension of the original construct. Thus, what the factor analysis did was not simply to increase the number of constructs from four to eight, but, more fundamentally, it allowed for the emergence of a mid-level set of attributes higher than the individual variables originally generated for each of the four constructs (see Table 3). 
Table 3

Modified Construct Descriptions Extracted through Factor Analysis

\begin{tabular}{|c|c|c|c|}
\hline Factor & Modified construct description & $\begin{array}{l}\text { Shortened } \\
\text { label }\end{array}$ & $\begin{array}{l}\text { Reliability } \\
\text { coefficient }\end{array}$ \\
\hline 1 & $\begin{array}{l}\text { Collaborative learning - likes participating in } \\
\text { team work }\end{array}$ & $\begin{array}{l}\text { Collaborative } \\
1\end{array}$ & 0.915 \\
\hline 2 & $\begin{array}{l}\text { Instrumental learning - needs to rely on the } \\
\text { guidance of an 'expert'. }\end{array}$ & $\begin{array}{l}\text { Instrumental } \\
1\end{array}$ & 0.772 \\
\hline 3 & $\begin{array}{l}\text { Independent learning - welcomes } \\
\text { opportunity to set own goals }\end{array}$ & $\begin{array}{l}\text { Independent } \\
1\end{array}$ & 0.774 \\
\hline 4 & $\begin{array}{l}\text { Collaborative learning - is comfortable } \\
\text { accepting peer evaluation }\end{array}$ & $\begin{array}{l}\text { Collaborative } \\
2\end{array}$ & 0.733 \\
\hline 5 & $\begin{array}{l}\text { Interactive learning - is capable of } \\
\text { articulating own viewpoint in an exchange. }\end{array}$ & Interactive 1 & 0.619 \\
\hline 6 & $\begin{array}{l}\text { Independent learning - maintains focus on } \\
\text { the path to achieve desired outcomes }\end{array}$ & $\begin{array}{l}\text { Independent } \\
2\end{array}$ & 0.585 \\
\hline 7 & $\begin{array}{l}\text { Interactive learning - draws on input from } \\
\text { other agents to strengthen and/ or improve } \\
\text { own learning. }\end{array}$ & Interactive 2 & 0.563 \\
\hline 8 & $\begin{array}{l}\text { Interactive learning - welcomes opportunity } \\
\text { to engage with others to activate own } \\
\text { cognitive processes. }\end{array}$ & Interactive 3 & 0.538 \\
\hline
\end{tabular}

As noted above, there were also some shifts. Two such items are reviewed.

The item Oral interaction is more beneficial when studying online than written interaction was developed as a variable of the construct Interactive learning. After factor analysis, it loaded on Factor 2 with four other items that were originally developed as examples of instrumental learning. One can argue that a possible factor giving rise to this shift is that students consider oral interaction to be a more reliable means for them to communicate directly with and draw information from a credible source of knowledge. 
The second, You are comfortable holding a point of view that is different from what the majority thinks, was originally developed as an attribute of Independent learning, but it loaded on Factor 5 with two other items, previously defined as variables of interactive learning. When viewed in relation to the other two, one notes that all three reflect an ability on the part of an individual to hold to one's perspectives when dialoguing with others.

Returning to Factor 2, the last item to load on that factor deserves further attention. You welcome guidelines that give you alternative approaches for doing an assignment was originally included within the instrumental learning category, and intended for reverse scoring. It was assumed that respondents who were tending towards instrumental learning approaches would not respond positively to this item. This was not the case. The relative strength of this item in this factor suggests that, very likely, students' thinking about their own approach to learning differed from the understanding implied in this item.

Even though one accepts the confirmation of the eight factors, one cannot ignore the weak reliability coefficient for three of them, namely Factor 6, labelled as a dimension of Independent learning and Factors 7 and 8, labelled as dimensions of Interactive learning. However there are grounds to support their retention.

With regard to Factor 6, it would appear that the initial decision to include the item Doing the session and reading review questions is an important aspect of your study of the course, in the instrumental learning category, may not have been very appropriate. A strong case can be made for it to be considered as an attribute of independent learning on its own strength. Moreover, it appears to share the same core attributes as the second item, You have an organized way of making notes when you study, which was initially categorized as independent learning. On the other hand, both of these appear to be in contradiction of the third item, You think that all work that you submit to the group facilitator should be graded, given a perspective that students who place heavy emphasis on grades are displaying an instrumentalist perspective on learning. It is likely that this inherent tension among the items accounted for the weak reliability score. Notwithstanding, the researcher is of the view that there is value in retaining the factor and the orientation of the first two items was used to name it.

With regard to Factors 7 and 8, one recalls that, in the review of the literature, it was noted that some theorists view all learning that involves interpersonal interaction as collaborative learning and do not attempt to distinguish between different levels or forms of the communication. Drawing on other sources, this researcher argued that a distinction could be made between the two, notwithstanding the areas of overlap. Thus, for the purpose of this study, the decision was made to generate two separate constructs.

It is evident however that the two components described as dimensions of collaborative learning emerged in a stronger position than the three described as aspects of interactive learning. However, the fact that Factors 7 and 8 (along with Factor 6) were 
actually extracted suggests that the decision to maintain interactive learning as a construct in its own right was justified. For that reason, the dimensions of this construct, as reflected in Factors 7 and 8, are being retained.

The emergence of one dimension of collaborative learning and another of instrumental learning as Factors 1 and 2 is to be noted. It is likely that students do not perceive any inconsistency in having an equally strong preference for both these learning modes. However, on examination of the open-ended responses, one finds that the preference for the collaborative learning mode was not without some reservation. The following comments are to be noted:

Group work is important in the online environment, but could be frustrating when one member tends to dominate and refuse valuable input from peers.

I am comfortable working with group members ... [but] it is frustrating when your grade depends on others and they do not contribute the way that they should.

Other open-ended responses of some students appeared to reinforce instrumental learning approaches:

I learn best when I have excellent and understanding support systems (group facilitators/tutors) when doing readings and assignments.

Group facilitators need to provide more guidelines in having students master certain aspects of the course.

I don't like challenging facilitators especially online because you see it reflected in your grades...

Overall, when viewed through the lens of the academically recognised learning modes, student learning preferences reflect a complex of approaches ranging from the constructivist to the behaviourist.

\section{Conclusion and Recommendations}

The constructs around which this study was built were more or less confirmed as the preferred learning modes of UWI Open Campus graduate students. Not only were these constructs confirmed but factor analysis was able to identify and reveal different dimensions embedded within each. Three issues emerging from the study warrant some attention. 
The generation of the different dimensions of each of the original four constructs opens up scope for the development of more targeted teaching-learning strategies in the design of online learning environments. In this regard, the distinction made between interactive learning and collaborative learning in the design of the study and, thereafter, the wider range of dimensions emerging from these two separate constructs can be expected to allow for greater precision in defining the strategies best capable of facilitating each of these two learning modes.

The results of the study also seem to suggest that analysts and practitioners should be wary of elevating any single learning mode above another since the students themselves do not appear to be making that type of distinction. Specifically, the tendency to devalue instrumental learning behaviours in relation to others that are considered more appropriate may prove to be counter-productive. Designers of online learning spaces may find it more beneficial to use instrumental learning strategies as a platform to facilitate learner transition to more independent learning behaviours.

One positive of the results of the study is the strength of the two collaborative learningrelated constructs emerging after factor analysis. It is clear that this learning mode is a significant part of the way UWIOC graduate students perceive the way that they learn. At the same time, their responses to the open-ended questions cannot be ignored. It can be argued that the "frustrations" they experience arise from their limited awareness of what is required when participating in collaborative activity. Thus, all tasks that students should engage in as they participate in collaborative activities should be more clearly articulated. Knowing what each participant must do and what each can expect of every other participant is a key aspect of successful collaboration.

Finally, there is need for a follow-up study to investigate if and how these preferred learning modes relate to one another as a basis for making decisions about the design of online learning spaces. 


\section{References}

Anderson, T. (2008). Social software technologies in distance education: Maximizing learning freedoms. In T. Evans, M. Haughey \& D. Murphy (Eds.), International handbook of distance education (pp. 167-184). Bedfordshire, UK: Emerald Group Publishing.

Annand, D. (2007). Re-organizing universities for the information age. International Review of Research in Open and Distance Learning, 8(3). Retrieved from http:// www.irrodl.org.

Asunka, S. (2008). Online learning in higher education in Sub-Saharan Africa: Ghanaian students' experiences and perceptions. International Review of Research in Open and Distance Learning, 9(3). Retrieved from http://www.irrodl.org.

Candy, P. C. (1991). Self-direction for lifelong learning. San Francisco: J ossey-Bass Inc.

Cookson, P., \&Chang, Y. (1995). The multidimensional audio-conferencing classification system (MACS). The American J ournal of Distance Education, 9(3), 18-36.

Daniel, J . S., \& Marquis, C. (1988). Interaction and independence: Getting the mixture right. In D. Stewart, D. Keegan \& B. Holmberg (Eds.), Distance education: International perspectives (pp. 339-359). London: Routledge.

den Exeter, K., Rowe, S., Boyd, W. , \&Lloyd, D. (2012). Using Web 2.0 technologies for collaborative learning in distance education - case studies from an Australian university. Future Internet, 4, 216-237.

Devos, A. (2002). Gender, work and workplace learning. In F. Reeve, M. Cartwright \& R. Edwards (Eds.), Supporting lifelong learning, Vol. 2. (pp. 51-63). New York: Routledge Falmer.

Dixon, R., Dixon, K. , \& Siragusa, L. (2007). Individuals' perceptions of online environments: What adult learners are telling us. In ICT: Providing choices for learners and learning. Proceedings ascilite Singapore 2007. Retrieved from http:// www.ascilite.org.au/conferences/singapore07/ procs/dixon.pdf.

Duffy, T. M. , \&J onassen, D. H. (1991). New implications for instructional technology? Educational Technology, 31(5), 7-11.

Gray, R. (1996). Archetypal explorations: An integrative approach to human behaviour. NewYork: Routledge. 
Harasim, L., Hiltz, S. R., Teles, L., \&Turoff, M. (1995). Learning networks: A field guide to teaching and learning online. Massachusetts: The MIT Press.

Haughey, M., \&Anderson, T. (1998). Networked learning: The pedagogy of the internet. Montreal: Cheneliere/ McGraw-Hill.

Haythornthwaite, C. (2006). Facilitating collaboration in online learning. J ournal of Asynchronous Learning Networks, 10(1), 7-24.

Hendricks, N. (2012). An e-learning collaborative environment: Learning within a masters in education programme. International J ournal on E-Learning,11(1), 39-53.

Henri, F. (1992). Computer conferencing and content analysis. In A.R. Kaye (Ed.), Collaborative learning through computer conferencing.The Najadeen papers (pp. 117-136). Berlin: Springer-Verlag.

Hong, S., \&J ung, I. (2011).The distance learner competencies: A three-phased empirical approach. Education Technology Research and Development, 59, 21-42.

Hyland, T., \& Merrill, B. (2003). The changing face of further education: Lifelong learning, inclusion and community values in further education. New York: Routledge Falmer.

J ahng, N. (2012). An investigation of collaboration processes in an online course: How do small groups develop over time? International Review of Research in Open and Distance Learning, 13(4), 1- 18. Retrieved from http:// www.irrodl.org

J egede, O. (1991). Constructivism and research in distance education. Open Forum: Distance Education and Open Learning, 1(1), 5-9.

J onassen, D., Davidson, M., Collins, M., Campbell, J ., \& Haag, B.(1995). Constructivism and computer-mediated communication in distance education. The American J ournal of Distance Education, 9(2), 7-26.

Kuboni, O. (2009). From lecturer to course coordinator: Redefining the role of the university academic for teaching and learning in a distribiuted learning environment. J ournal of Online Learning and Teaching, 5(1), 138-148. Retrieved from http://jolt.merlot.org.

Kuboni, O. (2011). What is the preferred learning mode of mature students in an online graduate programme? In Proceedings of World Conference on E-Learning in Corporate, Government, Healthcare, and Higher Education 2011 (pp. 23812386). Chesapeake, VA: AACE. Retrieved from http:// www.editlib.org/p/39087. 
Laurillard, D. (1993). Rethinking university teaching: A framework for the effective use of educational technology. London: Routledge.

Merriam, S. B., Caffarella, R. S. \& Baumgartner, L. M. (2007). Learning in adulthood: A comprehensive guide ( $3^{\text {rd }}$. ed). California: J ossey-Bass.

Moore, M. (1973). Toward a theory of independent learning and teaching. J ournal of Higher Education, 44(12), 661-679.

Moore, M. (1989). Three types of interaction. The American J ournal of Distance Education, 3(2), 1-6.

Nichani, M. R. (2000). Learning through social interactions (online communities). Elearningpost.com. Retrieved from http://www.elearningpost.com

Postle, G. (2002). Emergence of fourth generation technologies. Retrieved from file:// G|/Projects/web/e-jist/ site/ docs/html2002/gPos.html

Rovai, A. (2002). Building sense of community at a distance. International Review of Research in Open and Distance Learning, 3(1), 1- 16. Retrieved from http:// www.irrodl.org

Rust, C. (2009). Assessment standards: a potential role for subject networks. J ournal of Hospitality, Leisure, Sports and Tourism Education, 8(1).

Ryle, A., \& Cumming, K. (2007). Reflections on engagement in online learning communities. International J ournal of Pedagogies and Learning, 3(3), 35-46.

Shackleford, J ., \& Maxwell, M. (2012). Sense of community in graduate online education: contribution of learner to learner interaction. International Review of Research in Open and Distance Learning, 13(4), 228 - 249. Retrieved from http:// www.irrodl.org

Wedemeyer, C. A. (1975). Implications of open learning for independent study. Paper presented at the ICCE Conference, Brighton, United Kingdom.

Yang, Y-F., Yeh, H-C ., \&Wong, W-K. (2010). The influence of social interaction on meaning construction in a virtual community. British J ournal of Educational Technology, 41(2), 287-306. 
Athabasca University $\mathbf{A}$

(c) 